\title{
Lenguaje, nación y Estado: pasado y presente
}

\section{Language, Nation, and State: Past and Present}

ROMAN SZUL *

\begin{abstract}
The three elements: language, nation and state have been interrelated. Three types of interrelations can be distinguished: 1) language-nationstate, 2) nation-language and state, 3) state-nation and language. These types have been active especially in Europe since the $19^{\text {th }}$ century, and in countries and regions following European example, including present cases of nationalism and ethno-regionalism. In recent decades language policies became more tolerant towards non-national indigenous languages (not necessarily towards immigrant languages) and new nationalist or regionalist movements emerged aiming at promoting their languages. They encounter problems with elaborating and spreading of standard national languages because the population addressed is already literate in another standard language. The paper examines various types of language situation resulting from the above processes.
\end{abstract}

Keywords: language, nation, state, language policy.

\section{Resumen}

El lenguaje, la nación y el Estado son tres elementos interrelacionados. Es posible distinguir tres tipos de interrelaciones: 1) lenguaje-nación y Estado, 2) nación-lenguaje y Estado, 3) Estado-nación y lenguaje, las cuales han estado en uso desde el siglo xix, especialmente en Europa y en países y regiones que siguen a Europa como ejemplo, incluyendo casos de nacionalismo y etnoregionalismo. En décadas recientes las políticas de lenguaje se han vuelto más tolerantes con los lenguajes indígenas no nacionales (no necesariamente con las lenguas de imigrantes), generando nuevos movimientos nacionalistas o regionalistas que promueven dichos lenguajes. Estos movimientos tienen problemas para elaborar y difundir las lenguas nacionales estándar, puesto que las poblaciones a las que van dirigidas ya están alfabetizadas en otra lengua estándar. Este artículo examina varios tipos de situaciones lingüísticas resultantes de los procesos mencionados.

Palabras clave: lengua, nación, estado, política lingüística.

*Universidad de Varsovia, Polonia. Correo-e: r.szul@chello.pl. 


\section{Introduction}

The three elements: language, nation and state are strictly interconnected and mutually influencing, especially since the $19^{\text {th }}$ century, when the modern idea of nation emerged and when the issue of language became highly politicized. The tendency in the $19^{\text {th }}$ and $20^{\text {th }}$ century in Europe and in parts of the world populated by Europeans or following European example was to unite these three elements: every language having its nation and state, every state being populated by only one nation using one language. ${ }^{1}$ Despite this mutual interconnection and mutual influence, one can observe that in certain situations, certain periods of time and certain countries one of these elements had a lead - it emerged as the first one and influenced the other two. In such a way there are (or there were) various ways to the (never achieved) unity of language, nation and state. Each of those ways has its own dynamics that deserves attention in nationalism studies.

Efforts to achieve this unity took place in different circumstances as regards progress of modernity, thus producing different results. Generally speaking, two kinds of circumstance can be distinguished: 1) pre-modern or modern, and 2) postmodern. ${ }^{2}$ While in pre-modern and modern language policy language played a double role of means of communication and symbol of collective identity, in postmodern language policy it is predominantly the role of language as symbol of identity that is in the centre of concern. Consequently, while in modern language policy spreading of a national language was also spreading of literacy, of general education, of national idea as well as integrating their (present and future) speakers into a nation by providing common means of communication and symbol of identity, in post-

${ }^{1}$ An illustration of this tendency was the Woodrow Wilson's idea of the right of nations to independence, which implicitly or explicitly identified nations with language communities. See: "It was at the Paris Conference in 1919 that Woodrow Wilson, who had come to Europe with his 'fourteen points' defending the right of nations to selfdetermination, was asked: 'Must every little language have a country of its own?' The answer, apparently, was 'Yes', and the Treaty of Versailles ensured that out of the dissolution of the four empires numerous small states were born (Sakwa y Stevens, 2006: 7).

${ }^{2}$ The term postmodern is used here in a sense attributed to it in contemporary sociology. Some sociologists prefer the term late modern for the same meaning. General characteristics of modernity in this meaning is policies carried out by nation states or nationalist movements aimed at industrialisation, urbanization, literacy, cultural and political homogenisation of the population, etc., inspired by the idea of a uniform model of progress. Postmodern or late modern politics resigns from the idea of a uniform model of progress, admits greater cultural and political diversity of the population, as well as revalorizes nature instead of urben and industrial growth. 
modern circumstances spreading or defending a national language is often deprived of the element of modernization as people are already literate and educated, although in a wrong language. This situation creates often a tension between the need to protect or promote a language (especially of old ethnic minorities) as symbol of identity on the one hand, and a low market value of this language and too little interest to preserve or recover it by its (actual and would-be) users, on the other. At the same time, literacy of "new" (immigrant) minorities and their access to information in their native languages via contemporary means of communication (internet, satellite TV, etc.) reduces their dependence on communication in languages of host countries thus creating a challenge to policies of their linguistic, cultural and emotional integration with the host society.

This paper tries to highlight the various ways of interconnections between language, nation and state in the past (in pre-modern and modern times) and to point out present problems in implementing language policies of some new states and national movements and in some immigration countries that try to follow past language policies.

\section{The three types of relation between language, nation and state}

As mentioned earlier, three types of relation between language, nation and state can be discerned throughout the history:

- State $\rightarrow$ language and nation. In this situation state is the first and independent element. Within state boundaries, with or without conscious policy, a common language, later on called national language, emerges pushing out other language varieties to territorial and/or social margins. This process is parallel to formation of a nation-a community sharing common ideas, values, myths, and being aware of forming a community and willing to remain a community.

- Language $\rightarrow$ nation $\rightarrow$ state. The first is language. The spread of a prestigious linguistic variety in a territory composed by various states, or the spread of awareness of speaking the same language, creates a community of its users which gradually becomes a nation. This nation tries to create a nation state by removing (or uniting) existing states or by breaking out from the existing state(s). If succeeded, the new nation state tries to continue the policy of one state- 
one nation-one language by implementing national conscience and spreading national language.

- Nation $\rightarrow$ language and state. The first is nation without a language (as an effective means of communication) and without a state. This was the case of communities integrated by religion or civilization and deprived of statehood. Following the examples of the two previous types of nationalism, such nation faces the problem of language as both symbol of identity and means of communication, as well as tries to build a nation state. If succeeded, such a state faces, again, the problem of nation-building and a language problem. Solution of the latter may be different from what was planned earlier.

The first type is typical for Europe, especially for western Europe. ${ }^{3}$ France is often quoted as the exemplary case of this type. The same can be said of England (and the United Kingdom in general), ${ }^{4}$ Spain, Portugal, the Netherlands, Sweden, Denmark, and Russia. Similar developments occurred outside Europe in Japan, Thailand, China, Turkey, Persia (Iran) and Ethiopia. It is interested to note that the mentioned non-European states consciously tried, since the late $19^{\text {th }}$ century, to emulate the (western) European model of state-language-nation relations as a policy of modernization.

In this context the case of Poland deserves attention. Until its collapse and partitioning of its territory between the three empires -Russia, Prussia and-Austria at the end of the $18^{\text {th }}$ century, Poland did not differ from the above western European countries. There was a strong (although socially limited) sense of national identity and a well developed national language. Consequently, at the beginning of the $19^{\text {th }}$ century Poles were a kind of state nation without a state. Later on in the $19^{\text {th }}$ century, however, some changes took place within Polish nation, namely its ethnicisation and democratisation. The ethnicisation meant that social and emotional bounds resulting from belonging (and yearning) to the same state were gradually waning out resulting in dropping out of ethnic fringes (Ruthenians/Ukrainians, Byelorussians, Lithuanians and others) from the Polish state nation. What remained were ethnic Poles or people speaking Polish and con-

${ }^{3}$ See for details, Wright 2004.

${ }^{4}$ The mechanism of emergence of national languages in France and Britain and downgrading of other languages is described in Jugde 2007. 
fessing Roman Catholicism (Szporluk 2003). The democratisation, as elsewhere, meant that the national idea and knowledge of standard Polish spread to lower social strata (peasants became Poles). When independent Poland re-emerged after the first world war, it tried to follow the French-style one state -one nationone language policy, although with some exceptions resulting from internal and external circumstances (e.g. recognition of national minorities with their linguistic rights).

Similar tendencies to those in Poland were characteristic also to Hungary, where a process of separation of the Hungarian (Magyar) ethnic nation from the state (or gentry) Hungarian nation occurred in the $19^{\text {th }} / 20^{\text {th }}$ century. A dramatic evidence to this separation was the change of official language of Hungary in the 1830 s -from Latin to Magyar. Despite this evident change Hungary in the $19^{\text {th }}$ century firmly proclaimed its adherence to the French-style idea of civic state nation where all inhabitants of Hungary were considered as Hungarians.

When talking about states which created nations and languages one must mention a special case of artificial states which emerged suddenly as a result of foreign intervention or being abandoned regions of disintegrated states. Such states if encompassing territories populated by peoples speaking various languages and having various ethno-national identities have to solve problems of the lack of common accepted and/or mastered language and the lack of national identity. In contemporary Europe it is the exemplary case of Belgium (Swennen, 1999), but also of Bosnia and Herzegovina, Macedonia, Moldavia, Ukraine and Belarus. Outside Europe it is the case of many post-colonial states, mostly in Africa. As regards their language problem, some of them try to develop and promote a genuine national language (as in the case of Ukraine against opposition of Russian speakers), some the facto adopt language of the former state they belonged to (most former African colonies of European empires) or combine indigenous languages with languages of the former state and of a neighbouring country (Belgium using French and Dutch, Moldavia de facto using Romanian and Russian, Belarus -Russian and, theoretically, Byelorussian, Macedonia using Macedonian and Albanian; outside Europe e.g. the republic of South Africa with its theoretically 11 official languages out of which only English and Afrikaans functioning as nation-wide languages, Tanzania using English and Swahili, Arabic countries sticking to classical Arabic and, for some purposes, English or French, etc). 
The USA combines the western European and post-colonial type of relations between language, nation and state. It is a state whose core area was a European colony, hence its language is a European colonial language (with all differences between the two Englishes). Further territorial expansion of the USA and national and linguistic integration of its populations resemble processes that took place centuries ago in France or Britain.

A slightly different combination of western European and postcolonial type is represented by Mexico (Nolasco, 1996; DíazCouder, 1997; Pellicer, 1997). At the beginning of the $19^{\text {th }}$ century when Mexico became independent, it was a former European colony without a sense of national identity and with official language (Spanish) spoken by a minority of its inhabitants and being a symbol of colonial dependence. Then Mexico embarked on the European style project of nation-building and modernization with Spanish as the national language, just for pragmatic reasons. Quite paradoxically, Mexican nationalism pretending to represent indigenous Indian culture and declaring respect for Indian languages, did more for expansion of Spanish and contraction of Indian languages than Spanish colonial authorities did. Urbanization and industrialization contributed to this process. As a result now vast majority (about 90\%) of the Mexican population are Spanish monoglots.

The second type (language $\rightarrow$ nation $\rightarrow$ state) has two subtypes. The first consists in spreading of a prestigious language and national awareness across state (usually pre-modern feudal statelets) borders eventually leading to unification of these states into one nation state. In Europe these are the well known cases of Germany and Italy united in the second half of the $19^{\text {th }}$ century. In the case of Germany this initial integrating highly prestigious language was the language of Martin Luther's translation of the Bible considered simply as model of standard German. Prestige of this language resulted more from its role in promoting Protestantism than from its internal characteristics. After being accepted in protestant countries, it was also accepted by German Catholics. In the case of Italy, the uniting prestigious language was the Tuscany dialect of famous writers - Dante, Bocaccio, Petrarca, promoted by Tuscany princes. Since the $16^{\text {th }}$ century it became language of educated people, their means of communication as well as symbol of Italianness. It is interesting to note that acceptance of standard German or standard Italian as literary or official language not always lead to adoption of 
German or Italian national identity and to the idea of building or joining the German or Italian nation state. It is the case of Switzerland using German, Italian (and French) as official languages.

Similar characteristics to those revealed by Germany and Italy can be found in Romania (Popa, 2000). Until the creation of the Romanian state in the second half of the $19^{\text {th }}$ century (exactly in the same time when Germany and Italy were uniting), there were three semi-independent states -the Duchy of Valachia, the Duchy of Moldavia and the Duchy of Transylvania. (The latter was populated mostly by peasants of Daco-Romano-Slavic origin now called Romanians, but was ruled by Hungarian gentry). Until the $16^{\text {th }}$ century the official (chancellery) language of Valachia and Moldavia was church-Slavonic while in Transylvania it was Latin. The appearance of Romanian literary language (at first as a language of communication between Valachia and Transylvania) and its acceptance as official language in Valachia and Moldavia in the $16^{\text {th }}$ century and as national language of Romanians in Transylvania facilitated or generated the sense of Romanian national unity which eventually led to the above mentioned unification of Valachia and Moldavia, and to incorporation of (or unification with) Transylvania after the first world war.

The second subtype of the language $\rightarrow$ nation $\rightarrow$ state type took place in ethno-linguistic communities lacking a state and being subordinated to larger political units (states). Speaking a language different from the official or dominant language of the state, usually combined with the sense of injustice resulting from socio-economic (mostly peasant) or religious status and oppression by the state gave birth to the idea of belonging to a separate nation and the idea of nationalism ${ }^{5}$. In contemporary Europe several states, especially in central and eastern part of the continent have their roots in this type of evolution, to mention Slovakia, Slovenia, Latvia, Estonia, Finland, Albania as the clearest examples. The cases of Czechia, Serbia, Bulgaria and Lithuania reveal some characteristics of state nation without state although the memory of the lost statehood and linguistic heritage of the lost state were by far weaker here than in Poland.

The third type (nation $\rightarrow$ language and state) is best represented by the Jewish nationalism (Zionism), the rebirth of Hebrew

\footnotetext{
${ }^{5}$ This type of nations (sometimes called „small nations” and nationalism was extensively studied by the famous Czech scholar Miroslav Hroch, see his English language works Hroch 1996, 2004). On the question of various types of nationalism see a detailed overview in Hean 2006.
} 
as a vernacular language and the creation of the State of Israel. When analyzing Zionism it should be added that by the end of the $19^{\text {th }}$ century it was one of many ideas among the Jewish people in Europe and that Hebrew was not the only candidate for the role of national language of the Jews and of the State of Israel. For the founding father of Zionism, Theodore (Benjamin Tsvi) Herzl, the obvious language of the future Jewish State was German. Paradoxically, the rebirth of Hebrew in $18^{\text {th }}$ century Europe had little to do with Jewish nationalism. Hebrew was the instrument (for the lack of others, as Jews in that time could not read in any other language) of propagating of Haskala (Jewish Enlightenment) whose final goal was integrating Jews with nations of residence rather than promoting Jewish nationalism (Dieckhoff 2004).

Another example of a nation looking for language and state are the Irish in the $19^{\text {th }}$ and $20^{\text {th }}$ century. The fundament of Irish national identity was religion (catholic) and socio-economic status. The Irish people had two languages: English as the language of communication of most people, and Irish Gealic as a symbolic language of the Irish nation and as spoken language of a minority of the Irish. Attempts of Irish nationalists and of independent Ireland to make Irish not only a symbolic but also a widely used national and official language failed.

Outside Europe India can also be classified as a civilization pretending to be a nation, without a common language as both a symbol of unity and instrument of communication. Neither Sanskrit -the symbolic language of Hinduism, not Hindi- a would-be national language of India could play in practice the role of official nation-wide language. Such language is English -a former colonial language.

\section{Language policy in service of modernization and nationalism}

Language is not a given, unchangeable fact. It is always changing under influence of a lot of factors. Among them are policies carried out by governments of nation states and by national movements. There are three main areas of language policy:

- Corpus building, including standardization

- Status advancement

- Education diffusion 
Corpus building or planning aims at enriching the vocabulary (of special importance is terminology) and stylistic repertoire as well as standardization of the language. The purpose of this is to make the language able to function in as many spheres as possible and, at the same time, to increase its reputation. The adequate reputation is an indispensable precondition for the language to be accepted in the given sphere by its expected users.

Status advancement means introducing a language to more spheres $-e . g$. to everyday life (if it is not used here)-, to education, media, science, business, government, etc. While governments usually intend to introduce an official language to the private life of inhabitants or citizens of the given state, national movements try to introduce a community language to the public and official life of the state. An important and sometimes troublesome tasks is to convince that a given variety is a "language" and not a dialect, patois or jargon, and thus deserves entering higher spheres. Status advancement sometimes means introducing a language to a sphere to function there along with another language(s), and sometimes -instead of another language(s). Therefore status advancement has a strictly political meaning. This led to conflicts between state governments and national movements, so characteristic for the $19^{\text {th }}$ and early $20^{\text {th }}$ century Europe: on the one hand intolerance of state governments towards minorities and their languages, desire to eradicate these languages, at least to remove them from the public sphere, on the other hand ethno-national and irredentist movements believing that only creation of a separate independent state or joining "motherland" would create necessary condition for development of the given group's language, culture and identity, as well as to promote its economic interests (Jackson, 2007: 124-164; 2005).

Corpus building and status advancement are useless if the people meant to use the language don't master this language. Therefore language education and thus diffusion of language competence and enhancing proficiency in the given language are of extraordinary importance to any language policy. It should be remembered that language proficiency entails various skills, to some extent independent: speaking, understanding, writing and reading. A problem encountered by some language policy-makers is that sometimes people easily speaking a language have proble$\mathrm{ms}$ with writing or reading in it and, therefore, this language can not function properly in the public and official sphere. 
Language policy acquired special importance in Europe in the $19^{\text {th }}$ century as a part of a larger socio-economic and political project. This project can be called modernization and nationalism. Language policy of that kind entailed three interrelated aims:

- Nation identity building

- Literacy spreading

- Communication facilitating

Spreading knowledge of a standard national language to illiterate people was at the same time spreading literacy (any literacy!), providing a means of mutual communication of people from different regions and different social strata (necessary for smooth functioning of nation-wide markets, army, public institutions, etc.) as well as creating and inflicting the sense of national unity and identity of users of the language.

Needless to say, governments were in a better situation than non-governmental organizations (national movements) in carrying out language policy. Nevertheless, the latter also had a maneuver space, especially in more liberal societies or in weak empires, as, for instance, in the Habsburg and Ottoman empires, and, to some extent, in the Russian empire. The illiteracy of the vast majority of the population gave chance to educators (be governments or national movements) to teach the people a standard national language and to tell them that they belonged to such a such nation.

Such a policy was carried out in Europe in the $19^{\text {th }}$ and in the $20^{\text {th }}$ century. As a result of this policy and other factors, practically the whole population of Europe (except latest immigrants) masters national language of its country. Those who also speak another language (a minority language) are usually bilingual or diglossic. For a large part of the bilingual or diglossic people the official national standard language is their language of literacy in which they receive or have received education, read and write and communicate outside informal family contexts.

\section{Late or post-modern language policy}

The post-war period in Europe (and to a lesser extent outside it) ${ }^{6}$ brings about a significant change in attitudes towards non-

${ }^{6}$ Just to illustrate that the new situation is not limited to Europe, see Karimi 2008. The author directly relates movement for revival of a regional language in Iran (Azeri) to the post-modern type of connection between language and politics. 
official indigenous languages of states. On the one hand central governments and majorities become more generous towards these languages. They are no longer considered as obstacles or threat to national unity. What is more, they are often regarded as elements of cultural richness, and even as a tourist attraction of the given country or region. Even if this kind of reasoning is absent, state governments are generally less militant in fighting these languages. On the other hand there is increased agitation among defenders of minority languages, cultures and identities.

In some cases such agitation takes on the form of ethno-regionalist or nationalist movements aiming at gaining autonomy or independence for a given territory. In several cases these movements have managed to achieve their goals, or simply external circumstances (e.g. disintegration of the state) gave them a chance to fulfill their programmes. It is the case of ex-Soviet nonRussian republics after 1991, of Catalonia and Catalan countries, Bask Country and Galicia in Spain after the collapse of the Franco regime in 1975, of Wales especially after devolution in 1999, of Frisia in the Netherlands, of ethno-regionalist movements in France, Italy, Germany, Scandinavian countries (Saami people), etc. A constant element of these movements is language policy aiming at preserving or promoting of a given language.

This late or postmodern (in some cases it is, however, classical modern) language policy encounters problems resulting from massive literacy in a wrong language ${ }^{7}$ (e.g. in Spanish instead of Catalan or Bask, in Russian instead of Ukrainian or Belorussian, in English instead of Welsh or Irish, in Dutch instead of Frisian, in Italian instead of Sardinian or Friulan, in Polish instead of Kashubian, in German (Hochdeutsch) instead of Low German, etc. Sometimes they encounter problems resulting from wrong hierarchy of languages in a given territory, e.g. from the fact that Russian, and not Latvian or Estonian, is the language of interethnic communication and the main vehicle of socio-professional promotion.

In such a situation newly emerged states and ethno-regionalist or nationalist movements pursue language policies aiming at:

- Nation identity re-building (changing identity)

- New literacy spreading (implying language reversal)

- Communication re-shaping (language reversal)

${ }^{7}$ I owe the idea of wrong language of literacy to Byelorussian scholar Elena Gapova (2004). 
As can be seen, these aims are more related to identity and nationalism than to pragmatism and modernization. This is a major weakness because these policies appeal mostly to identity and emotions rather than to economic and social interest of the population. To remember: the old language policies offered education which opened up ways for economic and social promotion in vast territories of nation states or even in larger areas.

Proponents of the new language policies are aware of this weakness and suggest that using a regained (weaker) language doesn't exclude using, in some circumstances, another (i.e. stronger) language(s), for instance using of Ukrainian in Ukraine or Latvian in Latvia or Estonian in Estonia doesn't exclude using by the same Ukrainians, Latvians or Estonians of Russian when traveling to Russia or using English outside the former USSR; using of Catalan or Bask by a Catalan or Bask doesn't exclude speaking in Spanish in Madrid, in French in Paris, etc. This solution requires two things: bi- or multilingualism, which is not an easy thing, and a monopoly (linguistic niche) for the weaker language in a given territory. Otherwise, if two unequal languages are put on equal footing in a given territory or social network, the result will be the removal of the weaker by the stronger language.

To create such a niche strong political and economic measures must be applied, which are possible only in independent states and only if they are supported by a considerable majority of the population. In Latvia and Estonia it was denying citizenship to persons not mastering the national language and making access to higher positions in the economy conditional on knowledge of this language. Such policies generate resistance not only of the outsiders not knowing the local language but often also of "insiders" preferring a stronger external language to a weaker local one. It is why despite the formal status as national and official language Irish is still a minority language in Ireland, Belorussian a minority language in Byelorussia, why so many inhabitants of Catalan countries prefer speaking Spanish, etc. Changing this attitude would imply not only overcoming overt and passive resistance, but also often violating human rights and existing law. In democratic countries the law usually (although not always) offers some protection for minority language speakers to use their languages in certain situations, but never gives them the right to impose their language to those who don't wish to use it.

Not only new states and ethno-regionalist movements encounter obstacles in implementing their language policies. Old states 
have problems with implementing old-style policy of linguistic integration of new immigrants. There are three kinds of such obstacles: the idea of human rights (first of all language rights), free media market and new information and telecommunication technologies. While in the $19^{\text {th }}$ and in the first half of the $20^{\text {th }}$ century it was assumed that sovereign nation states had the right to linguistically assimilate immigrants using all necessary instruments (e.g. compulsory education in the national language, ban or constrains on use of foreign languages in schools, media and even in private, etc.) and immigrants themselves regarded such measures as legitimate or at least inevitable, now such practices encounter resistance of a part of immigrants and defenders of human rights (Extra and Yagmur, 2002). Although in comparison with linguistic rights of indigenous ethnic minorities, linguistic rights of immigrants are much less protected, immigrants are in a better legal position than earlier to defend their languages and identities if they wish so. The elimination of state monopoly in media and the role of market in this area means that if there is demand for spoken or written word in an immigrant language, the supply will appear (to mention Turkish language in Germany and Spanish in the USA). Contemporary information and telecommunication technology - internet, satellite TV, etc. -directly link immigrants with their home countries and their languages thus reducing necessity and probability of contacts with language of the host country.

\section{Types of post-modern language situations}

To better understand latest developments in language situation and policy, it seems useful to classify types of situations emerging form attempts at implementing language policies in late or post-modern contexts. The following types can be distinguished in countries and regions in Europe and outside it:

- Fragile bilingualism. The country or region has nominally two official languages: one being language of a narrower, and the other being language of a larger community. In practice the two languages have not equal practical value and the language of the narrower community is always threatened by the other one, and to protect the former, state or regional authorities must adopt administrative measures. For legal or political considerations these measures are li- 
mited, so they can help survive the weaker language but cannot reverse the situation. It is the case of Catalonia and Balearic Island (Catalan as the weaker and Spanish as the stronger language), Bask Country (Bask and Spanish), Wales (Welsh and English), Frisia (Frisian and Dutch); Ukraine and Moldavia also fell in this category although nominally they have only one official language (respectively Ukrainian and Moldavian/Rumanian) but in practice Russian still functions as the stronger language. Fragile bilingualism is also in Finland with its nominally two official national languages - Finnish and Swedish, the latter being the weaker (e.g. shrinking number: of native speakers - now about $5 \%$ of the population). In Norway there are two, nominally equal, varieties of Norwegian: the stronger bokmål (in fact the local version of Danish -language of the former rulers of Norwagia), and the weaker nynorsk (a variety based on local Norwegian dialects).

- Forced language reversal. The country or region in order to strengthen its weaker language takes political, administrative and economic measures to eliminate the hitherto stronger language from certain spheres, first of all from public administration, justice, higher grades of education and business. The general aim of this policy is to force speakers of the hitherto stronger language and immigrants to acquire the until now weaker language and to use it at least in the public life. The most successful examples of this policy are Latvia and Estonia (after independence in 1991 where local national languages replaced Russian) and Quebec (since the 1970s, where French replaced English). Other cases of non-Russian post-Soviet states are less obvious because either the local national language had been strong enough so a dramatic reversal was not needed (as in the case of Lithuania and Georgia) or the reversal is slow so that these republics fell better in the category of fragile bilingualism

- Decorative national language or linguistic symbolism. The country has in practice two languages: one being de facto functioning official language and the language of everyday life of most inhabitants, and the other being considered symbol of national identity which is used mostly as decoration, despite being officially the sole official or one of two nominally equal official languages. The most evident exam- 
ples of this situation are Ireland (Irish as symbolic and nominally official, and English as practical language) and Belarus (Byelorussian as nominally one of two official languages and symbolic language for some Byelorussians, and Russian as nominally one of two official languages, but practically the dominant language in all spheres). Elements of linguistic symbolism and "decorativism" can also be found in many cases classified as fragile bilingualism.

- Advancement of dialects into languages. Several language varieties until recently considered as dialects, or languages not worth or able of being used outside informal oral domains of uneducated people thus bound to disappearance, are regarded nowadays as languages (often called regional languages) worth of full esteem and promotion in the public life. Activists, sometimes supported by regional authorities, make efforts to use these languages in the public domain. However, their promotion in the public life, e.g. in school education, in media, etc. encounters problems resulting from the lack of standardization (to adopt one living form as standard?, to develop a compromise standard?, or to accept many varieties?), insufficient market for products and services in these languages, insufficient interest of would-be users (who are generally bilingual), low intergenerational transmission and still low prestige. Some examples of this situation in Europe: Scots and Scottish Gaelic in Scotland; Corsican, Breton, Occitan (Provencal), langues d'oïl (e.g. Picard), Alsatian in France; Low German, North Frisian, Upper and Lower Lusatian in Germany; Limburger and Lower Saxon in the Netherlands, Sardinian, Friulan, Ladin in Italy; Asturian (el bable) in Spain; Mirandese in Portugal; Kashubian in Poland, etc. Rhaeto-Romance in Switzerland in fact shares characteristics of this group of languages despite enjoying status of an official language at federal, regional (canton) and local level. Luxemburgish is probably the only language variety in Europe which in recent decades made a real, not only formal, advance from a dialect into a language.

- Language revival. Attempts at following revival of Hebrew. At best some dedicated individuals become bilingual and the revived language serves for symbolic and decorative purposes. The best known example in Europe is Cornish in the UK; Manx (Isle of Man) can also be mentioned. 
- Search for and change of language policy towards immigrants. Three types of such policy have been carried out parallel or alternatively in the main immigration countries over the last few decades: cultural and linguistic assimilation, civic acculturation and multi-lingualism (acquisition of host country's language while retaining home country's language), non-intervention (it's up to immigrants whether they learn the local language or retain their home language). After 2001 a new emphasis has been put on linguistic integration and assimilation of immigrants in such countries as Germany, Austria, the Netherlands and Belgium. France is traditionally assimilationist although recently with less success than earlier. The USA, Canada (except Quebec) and Australia after the second world war switched their policy from assimilation towards multi-lingualism or non-intervention (with some reservations concerning, e.g. citizenship requirements).

\section{Final remarks}

Language, nation and state are interrelated. Their interrelation intensified in the $19^{\text {th }}$ and in the first half of $20^{\text {th }}$ century with the advance of the idea of nation state and modernity. Language became an extremely political issue. For the then existing states, language -the one state or national language- became an instrument uniting citizens into nation, an instrument of modernization, and was a symbol of national identity. Existing of other languages within state boundaries was a challenge for the national unity and political stability, therefore there were attempts at eliminating them, at least from the public sphere, at downgrading them into dialects, at preventing upgrading speech varieties into "languages". For stateless communities having an own language -standard national language- was a proof of being a nation and having the right for self-determination. Therefore they made efforts to upgrade their speech varieties into fully-fledged standard languages or even to invent or revive a national language. Sometimes these attempts failed and states created by such communities had to have at least two languages: an instrument of communication and administration, and the other one as symbol of national identity.

After the second world war in western Europe and in other parts of the world linkages between language, nation and state 
somehow weakened. Nation-states became more generous towards traditional languages on their territories. Using other language than the official state language ceased to be regarded as a threat to territorial integrity of the nation state, and ceased to be treated as demonstration of disloyalty towards the state. In this new atmosphere ethno-regionalist or nationalist movements emerged or intensified their activity at defending and promoting languages other than official state languages. Their efforts encounter, however, obstacles resulting from the fact that the population addressed by such activity was mostly bilingual and literate in a state language and treated the state language as a vehicle for social and economic promotion. In such a situation these movements have either to appeal to arguments of identity and ethnic cohesion (leaving aside economic value of languages) or to create, by political means, socio-economic and political niches where the promoted language can survive without competition. The latter happened in some new states that emerged after the disintegration of the USSR leading to a new wave of politization of language. The new interest in cultural and linguistic integration of immigrants in some western European countries after 2001 increased, again, the political significance of language.

As can be seen from the above discussion the relationship between language and power has changed over the history -from relative separation between them in pre-modern times (rulers and ruled speaking different languages, no intention to impose one language to the whole society) to strong relations between them in times of modernity and nationalism (doctrine of one state-one nation-one language) when a hierarchy of strong and weak languages was shaped within nation states, to postmodern weakening of this relation and a greater tolerance towards and greater interest in maintenance of weaker indigenous languages, still to renewed pressure of linguistic assimilation of immigrants in some countries of immigration. The above changes has taken place in various historical, political, economic, demographic, geographic and even technological conditions thus producing various outcomes. These outcomes were classified above as types of relations between language, nation and state, and as types of the present post-modern language situations. 


\section{References}

Díaz-Couder, Ernesto (1997), "Multilingüismo y Estado-nación en México”, www.teluq.uquebec.ca/diverscite/entree.htm.

Dieckhoff, Alain (2004) "Hebrew, the Language of national Daily Life", In Tony Judt and Denis Lacorne (eds.), Language, Nation, and State. Identity Politics in a Multilingual Age, Palgrave Macmillan, Basingstoke, pp. 187-200.

Extra, Guus and Kutlar Yagmur (2002), Language diversity in multicultural Europe. Comparative perspectives on immigrant minority languages at home and at school, Discussion Paper 63, uNESCO, www.unesco.org/most/discuss.htm.

Gapova, Elena (2004), "Nationalism as Class: Belorussian Intellectuals and the Political Economy of the national Language", Warsaw Special Convention of the ASN, July 18-21.

Hroch, Miroslav (1996), "From National Movement to the Fully-formed Nation: The Nation-building Process in Europe", in G. Balakrishnan (ed.), Mapping the Nation, Verso, London.

Hroch, Miroslav (2004) "From Ethnic Group Toward the Modern Nation: The Czech Case, Nations and Nationalism", Journal of the Association for Study of Ethnicity and $\mathrm{Na}$ tionalisms, 10, Blackwell Publishing, Oxford, pp. 95-108.

Jackson-Preece, Jennifer (2005), Minority Rights, Polity Press, Cambridge.

Judge, Anne (2007), Linguistic Policies and the Survival of Regional Languages in France and Britain, Palgrave Macmillan, Basingstoke.

Karimi, Ali (2008) Globalization and ethno-linguistic revivalism in contemporary Iran: the case of Azeris (Azerbaijanis), in T. Siwek and V. Baar (eds.), Globalisation and its impact on localities, Ostrava, Czech Republic. 
Nolasco, Margarita (1996), “Lengua hegemónica, lenguas autóctonas: identidades diferenciadas”, www.teluq.uquebec.ca/ diverscite/entree.htm.

Pellicer, Dora (1997), "Reconomimiento y conocimiento de las lenguas indígenas de México”, www.teluq.uquebec.ca/di.

Popa, Nicolae (2000), "Elemente de unitate ${ }^{\circ} \mathrm{i}$ alteritate în spaciul geografic românesc (II)", Revista Românã de Geografie Politicã, II (2), Universitatea din Oradea, Oradea, Romania, pp.

Sakwa, Richard and Stevens, Anne, 2006, Contemporary Europe, Palgrave Macmillan, Basingstoke.

Swennen, René (1999), Belgique requiem, suite et fin? Complexe, Bruxelas.

Szporluk, Roman (2003), Imperium, Komunizm i Narody, Arkana, Krakow. Bruxelles.

Wright, Sue (2004), Language Policy and Language Planning. From Nationalism to Globalisation, PalgraveMacMillan, Basingstoke.

Recibido: 16 de febrero de 2009. Aceptado: 5 de mayo de 2009.

Roman Szul. Born in 1952, graduated from Faculty of Economic Sciences, University of Warsaw in 1976, PhD in economics in 1982, professor at the University of Warsaw. In has two academic fields of interest: economic sciences (including economic geography regional policy and development) and socio-linguistic and related studies (nationalism, regionalism, geography of languages). On the latter subject he wrote several articles in Poland and abroad, on general issues of socio-linguistic, language situation and policy in the European Union, on the relationship between economic conditions of expansion or decline of languages, etc. 